УДК 025.321:001.811:303.71

DOI: https://doi.org/10.32405/2663-5739-2018-2-93-98

\title{
В. В. Горак
}

кандидат історичних наук, старший науковий співробітник відділу наукової реферативної та аналітичної інформації у сфері освіти ДНПБ України імені В. О. Сухомлинського, м. Київ, Україна

\section{МІЖНАРОДНІ СИСТЕМИ ІДЕНТИФІКАЦІЇ ВЧЕНИХ ЯК ПОКАЗНИК ІМІДЖУ НАУКОВЦЯ}

У статті визначено поняття іміджу вченого. Проаналізовано й виокремлено певні критеріальні особливості та функціональні можливості міжнародних систем ідентифікації науковців. Встановлено, що реєстрація та створення профілів у таких комунікаційних системах $є$ бажаною умовою ідентифікації вченого, дієвим фактором підвищення його фахової компетентності. З'ясовано, що згадані системи уможливлюють ефективний пошук як паралельних розробників наукової проблематики, потенціальних співавторів та опонентів, так і передбачуваних споживачів наукової продукції. В той же час це й розширений пошук джерел фінансування науково-дослідної діяльності. Акцент зроблено й на популяризації власних досліджень, налагодженні міжнародних зв'язків 3 метою входження українських науковців та репрезентованих ними установ у світовий науковий простір. Автор наголошує про актуальність просування наукового доробку вітчизняних учених до міжнародних і світових наукометричних баз даних, що дає змогу не тільки ділитися досвідом, а й враховувати думку зарубіжних дослідників задля об'єктивності отримання проміжних і кінцевих результатів дисертаційної діяльності і планових НДР. Автор наводить стислу характеристику більш популярних ідентифікаторів (систем ідентифікаторів), що нині є найбільш важливими для діяльності ученого сьогодення, таких, як: Scopus Author ID ResearcherID Open Researcher and Contributor ID (ORCID) Google Scholar Research Gate; зосереджує увагу на необхідності присвоєння реєстраційним Crossref агентством ідентифікаторів DOI (Digital Object Identifier) кожній авторськійпублікації. У статті говориться й про те, що демонстрація та популяризація наукової діяльності ученого відбувається засобами соціальних мереж таких, як: Facebook, LinkedIn, Twitter та ін.

Ключові слова: ідентифікація, комунікація, соціальна мережа, ORCID, ResearcherID, Google Scholar, DOI.

Постановка проблеми. Системи ідентифікації вчених $є$ важливим елементом нинішнього глобалізованого світу. Це не тільки вимога часу, а й нагальна потреба сьогодення. Сучасні темпи глобалізації та інтеграції у світовий простір не змушують науковців до участі в цих процесах. Учений має бути впізнаваним, активним дослідником, учасником різноманітних наукових заходів, тренінгів, користувачем соціальних мереж, «йти в ногу 3 часом», постійно розвиватися. Важливим є створення профілів у системах ідентифікації вчених, що 
дає можливість контролювати власний список наукових напрацювань, шукати співавторів, знаходити джерела фінансування тощо. Крім того, така потреба часу підкріплена офіційними документами.

У 2015 р. Україна стала асоційованим членом Рамкової програми Свропейського Союзу з досліджень та інновацій «Горизонт 2020». У матеріалах документа наголошується на важливості єдиної ідентифікації вчених за допомогою стабільних неприватних відкритих систем, таких як ORCID [1].

Аналіз останніх досліджень і публікацій. У сучасній історіографії проблема формування іміджу вченого привертає увагу багатьох дослідників, оскільки в інформаційному суспільстві тема наукової комунікації набуває дедалі більшої актуальності. Зокрема, ці питання досліджувалися в працях А. Шостака [12], Т. Борисової [2], С. Назаровця [5] та ін.

Мета статті - проаналізувати вплив міжнародних систем ідентифікації вчених на створення іміджу науковця.

Виклад основного матеріалу. Формування репутації сучасного науковця $є$ складним, багатофакторним процесом і розглядається як єдність його фахового визнання та публічного авторитету [3]. Саме визначення іміджу трактується як цілеспрямовано створений образ, який формується на рівні масової свідомості, перетворюючись у відповідний стереотип, емоційно окреслений образ, що охоплює сукупність якостей, який асоціюється з певним індивідом [4, с. 127]. Поняття іміджу та бренда вченого часто ототожнюють. Під «брендом» розуміють сукупність уявлень, асоціацій, образів, ідей і обіцянок, що складаються у свідомості людей [9, c. 22].

Основою іміджу вченого є його наукові дослідження та досягнення, і чим вони якісніші, тим ефективнішим є його бренд [7].

Окрім здійснення наукових досліджень, учений має також популяризувати свою діяльність. Загальні уявлення про дослідника формують критерії його професійного статусу: науковий ступінь, вчене звання, кількість публікацій і цитувань, рецензії, відгуки, академічні та державні нагороди тощо [3]. Реальний імідж ученого можна виміряти кількома способами: публічним визнанням, використанням кількісних і якісних методів - контент-аналізу, індекс-цитування, 
імпакт-фактора тощо.

Упродовж десятиріч репутацію провідних науковців дедалі частіше вимірюють, орієнтуючись на рейтинг їхніх публікацій у міжнародній системі індексу-цитат (SCI - science citation index) та на сукупні дані цитування наукових журналів - імпакт- фактори або коефіцієнти впливу (JCR) [3; 12]. Індекс цитування (індекс Гірша) є найпоширенішим методом оцінювання рейтингу науковця, але не позбавлений певних недоліків. На думку багатьох експертів, цей індекс є лише одним із показників наукового рівня, якого досяг той чи інший учений, оскільки часто він залежить не стільки від якості роботи, скільки від PR-активності вченого. Сукупність цитувань - це не лише оцінка діяльності вченого, а й показник його наукової значущості, авторитетності [7]. У підвищенні іміджу вченого є не лише його особиста зацікавленість, а й тієї установи, де він працює, адже він впливає на загальний статус організації. Загальновідомо, що при складанні рейтингів закладів вищої освіти часто враховуються такі ключові показники, як кількість публікацій та цитувань науково- викладацького складу.

Упізнаваність ученого можна підвищити завдяки:

- наявності публікацій у журналах із високим імпакт-фактором та відкритих інформаційних системах;

- створенню профілів у професійних і соціальних мережах;

- застосуванню сервісів для збирання, оброблення, поширення та зберігання інформації;

- використанню глобальних ідентифікаторів (однозначна ідентифікація авторів і документів);

- розміщенню інформації на сайтах наукових установ [9, с. 23-24].

Міжнародна впізнаваність ученого залежить насамперед від його публікацій іноземною мовою та у виданнях, що індексуються впливовими міжнародними наукометричними базами, зокрема такими як Web of Science i Scopus. Найпоширенішими та найпопулярнішими міжнародними системами ідентифікації вчених є Scopus Author ID, Researcher ID, ORCID, Research Gate, Google Scholar.

Scopus Author ID - ідентифікатор автора, автоматично присвоюється 
кожному, хто має публікації, що індексуються в наукометричній базі Scopus.

Researcher ID - система ідентифікації авторів, створена для використання разом із базою наукової літератури у Web of Science. Реєстрація в Researcher ID доступна всім із будь-яких пристроїв і не потребує реєстрації Web of Science або наявності публікацій, проіндексованих у цій базі. Researcher ID дає можливість створювати профіль вченого, формувати список власних публікацій, створювати запрошення до співпраці, переглядати бібліометричні показники, пов’язати свій профіль із ORCID, системою управління бібліографічною інформацією End Note тощо [10].

Профілі авторів у системах ідентифікації містять таку інформацію як варіанти імені автора, перелік місць його роботи, кількість публікацій та цитувань, галузі досліджень, посилання на основних співавторів, індекс Гірша тощо [2].

Open Researcher and Contributor ID (ORCID) - відкритий, некомерційний проект для створення та підтримки реєстру унікальних ідентифікаторів дослідників, прозорого способу висвітлення науково-дослідної діяльності та вільного доступу до цих ідентифікаторів. Основна мета ORCID - розв'язати проблему ідентифікації вчених із однаковими іменами та прізвищами [10].

Ідентифікатор ORCID являє собою 16-значне число, унікальне для кожного автора. Обліковий запис містить інформацію про ім'я вченого, його електронну адресу, назву організації та інформацію про його дослідницьку діяльність. ORCID забезпечує контроль за поширенням цих даних і надає відповідні інструменти для управління рівнем їх приватності. Перевага ORCID - швидка реєстрація та можливість пов'язати різні унікальні ідентифікатори автора, такі як Scopus Author ID, Researcher ID, Google Scholar [10].

Google Scholar є некомерційною пошуковою бібліометричною системою, що індексує наукові публікації та наводить дані про їх цитування. Ця пошукова система викликає найбільшу зацікавленість українських науковців, оскільки такі платформи, як Web of Science або Scopus, опрацьовують менше ніж 2 \% публікацій українських учених, натомість в Google Scholar індексується більшість рецензованих он-лайн журналів Свропи та Америки [10; 11$].$

Research Gate - безкоштовна соціальна мережа та інструмент співпраці 
вчених із різних наукових галузей, що дає змогу спільно використовувати повні тексти наукових документів та обмінюватися ними, брати участь у фахових дискусіях тощо [10].

Фаховий i публічний бренд науковця $€$ взаємодоповнюючий, тому популяризувати власну діяльність можна не лише в системах ідентифікації чи під час створення профілів в наукометричних наукових базах, а й на просторах Інтернету, у виданнях, платформах, що мають вільний доступ до таких публікацій. Це ж стосується і соціальних мереж. Маючи профіль у такій комунікаційній системі, можна знаходити колег-однодумців, поширювати не лише особисті зацікавлення, а й праці, книги, заходи, які варто відвідати, відслідковувати новини за тематикою, підписатися на активних науковців. Отже, у такий спосіб популяризувати власну діяльність. Серед таких найбільш популярних соціальних мереж $є$ Facebook, LinkedIn, Twitter. Крім того, важливу роль у формуванні іміджу науковця відіграє рівень його комунікації: участь у науково-практичних конференціях, круглих столах, симпозіумах, фестивалях, виставках, виступах на радіо та телебаченні, публікації в ЗМІ тощо

Розв’язати проблему ідентифікації вченого можна також за допомогою DOI (Digital Object Identifier). Тим більше, що в наказі МОН «Про затвердження Порядку формування Переліку наукових фахових видань України» зазначено про обов'язкове присвоєння кожному опублікованому матеріалу міжнародного цифрового ідентифікатора DOI.

DOI - міжнародний стандарт (ISO 26324: 2012) ідентифікації інформації, який присвоюється науковим публікаціям, таким, як наукові статті, збірники наукових статей, анотації конференцій, доповіді конференцій, рецензії на наукові статті, дисертації, заявки на гранти, патенти, звіти про наукову роботу, підручники, наукові посібники, монографії [8]. DOI може містити різну інформацію, наприклад, назву, автора, адресу статті в Інтернеті (URL), інформацію про видання тощо.

Науковий контент DOI присвоюється реєстраційним агентством Crossref. B Україні з цим агентством офіційно співпрацюють видавничий дім «Інтернаука» та видавнича служба «Уран». У них можна замовити цифровий ідентифікатор DOI не 
лише для журналів, збірників, монографій, а й для кожної публікації окремо [8]. Крім згаданих вище систем ідентифікації можна виділити й інші: хмарний сервіс для зберігання й управління науковими документами «Figshare», відкритий депозитарій «ZENODO» та ін. Користувачам Research Gate, «Figshare» та «ZENODO» ідентифікатор DOI присвоюється безкоштовно [5].

У 2009-2011 рр. в Інституті інформаційних технологій і засобів навчання НАПН України на базі системи EPrints створено Електронну бібліотеку НАПН України. У депозитарій вносять публікації науковців усіх установ НАПН України, у тому числі й ДНПБ України ім. В. О. Сухомлинського. Крім того, створюючи профіль автора, фіксують особисті дані про науковця (місце роботи, посаду, ідентифікатор ORCID).

У НБУВ у межах проекту «Нова Україна: доступ до знань» запроваджено систематизований реєстр «Науковці України», призначений для проведення пошуку наукових видань і публікацій українських учених та пов’язаний із електронними бібліотечно-інформаційними ресурсами. Можливості системи дають змогу знаходити колег за суміжними напрямами наукових досліджень, переглядати інформацію бібліометричних профілів учених, завантажувати їхні публікації тощо [6]. У науковій бібліотеці Національного університету «Києво-Могилянська академія» пропонують послугу зі створення веб-іміджу ученого, зокрема допомагають у створенні й оптимізації профілю в популярних спеціалізованих наукових сервісах, таких як ORCID, Researcher ID, Google Scholar, Research Cate та iH. [11].

Висновки. Реєстрація профілю науковця в системах ідентифікації $\epsilon$ показником іміджу вченого й дає уявлення про його наукову діяльність. Системи ідентифікації уможливлюють запобігання помилкам у перекладі прізвищ учених, містять інформацію про кількість праць, показник цитування, спільний репозитарій публікацій. Профіль у таких системах може бути автоматично створеним звітом про здійснену наукову роботу за певний період. Крім того, системи ідентифікації учених $\epsilon$ місцем для пошуку співавторів, паралельних розробників наукової проблематики та опонентів. За допомогою таких систем можна відшукати інші джерела фінансування досліджень та налагодити міжнародні зв’язки. Фундаментом 
у створенні іміджу науковця є його масова комунікація: участь у наукових заходах, публікації в 3МI, виступи на радіо та телебаченні. Важливо також використовувати соціальні мережі, що в умовах сучасності стає одним із важливих засобів популяризації власної діяльності.

3 огляду на те, що показник іміджу є важливим і для науковця, і для установи, в якій він працює, реєстрація в міжнародних системах ідентифікації останнім часом набуває дедалі більшої актуальності. Така вимога стає загальноприйнятою. Варто враховувати, що якісні дослідження, опубліковані вітчизняними науковцями у впливових іноземних виданнях, сприяють інтеграції української науки в міжнародний освітньо-науковий простір.

\section{Список використаних джерел}

1. Березюк H. ORCID ідентифікація вченого [Електронний ресурс] / Наталія Березюк // Педагогічні науки. Переклад. - Текст. дані. - [Україна], 2016. - Режим доступу: http://edutranslate.wixsite.com/edutranslate/single-post/2016/06/17/ORCID-ідентифікація- вченого (дата звернення: 16.11.2018). - Назва з екрана.

2. Борисова Т. Розбудова іміджу науковця сучасними засобами наукової комунікації [Електронний pecypc] : тренінг для науковців / Тетяна Борисова ; Наук. б-ка НаУКМА // Національна медична академія післядипломної освіти імені П. Л. Шупика : [офіц. портал]. Текст. дані. - Київ, 2017. - Режим доступу: http://nmapo.edu.ua/images/Novosti/24_10_18- 1.pdf (дата звернення: 21.11.2018). - Назва 3 екрана.

3. Коновець О. Ф. Фахова та публічна репутація вченого: комунікативний аспект [Електронний pecypc] / Коновець О. Ф. // Наук. зап. Ін-ту журналістики / Київ. нац. ун-т ім. Тараса Шевченка. - Текст. дані. - Київ, 2007. - Т. 28. - Режим доступу: http://journlib.univ.kiev.ua/index.php?act=article\&article=1978 (дата звернення: 21.11.2018). - Назва з екрана.

4. Лаврентій А. С. Основні підходи до ідентифікації іміджу, його структурних складових та функціонального простору реалізації / А. С. Лаврентій // Інвестиції: практика та досвід. - 2017. - № 20. - C. $123-128$.

5. Назаровець С. Інструменти для організації відкритого наукового співробітництва [Електронний pecypc] / Сергій Назаровець // Професійний розвиток: відкриті ресурси, цифрова наука та міжнародні публікації : семінар, 5 груд. 2014 р. / Київ. шк. економіки. - Текст. дані. - Київ, 2014.

Режим доступу:

https://www.researchgate.net/publication/271324903_Instrumenti_dla_organizacii_vidkritogo_nauk ovogo_spivrobitnictva (дата звернення: 21.11.2018). - Назва з екрана.

6. Науковці України - новий інформаційний блок порталу «Наука України: доступ до знань» [Електронний ресурс] // Національна бібліотека України імені В. І. Вернадського : [офіц. портал]. Текст. дані. - Київ, 2017. - Режим доступу: http://www.nbuv.gov.ua/node/3565 (дата звернення: 21.11.2018). - Назва з екрана.

7. Парамонов С. Бренд ученого: как сделать так, чтобы нас цитировали [Электронный ресурс] / С. Парамонов // Clarivate Analytics. - Режим доступа: http://wokinfo.com/media/pdf/ru-researcher_brand.pdf (дата обращения: 21.11.2018). - Загл. с экрана.

8. Присвоєння DOI науковим виданням [Електронний ресурс] // Інтернаука : вид. дім. Текст. дані. - Київ, [б. p.]. - Режим доступу: https://www.inter-nauka.com/ua/services/doi/ (дата звернення: 21.11.2018). - Назва з екрана.

9. Семененко Л. П. Формування бренду ученого / Л. П. Семененко, Ю. М. Главчева, М. І. Главчев 
// Сучасні проблеми діяльності бібліотеки в умовах інформаційного суспільства : матеріали Шостої міжнар. наук.-практ. конф., 10-11 верес. 2015 р., Львів / Нац. ун-т «Львівська політехніка», Наук.-техн. б-ка. - Львів, 2015. - С. 22-27.

10.Системи ідентифікації науковця [Електронний ресурс] // Наукова бібліотека Чернігівського національного технологічного університету : [офіц. портал]. - Текст. дані. - Чернігів, [б. р.]. Режим доступу: http://library2.stu.cn.ua/na_dopomogu_naukovcyu/sistemi_identifikacii_naukovcya/ (дата звернення: 21.11.2018). - Назва з екрана.

11.Створення унікальних профілів дослідника в ORCID, Google Scholar та ін. [Електронний ресурс] // Наукова бібліотека Національного університету «Києво- Могилянська академія» : [офіц. портал]. Текст. дані. - Київ, [б. p.]. - Режим доступ: http://www.library.ukma.edu.ua/index.php?id=622 (дата звернення: 21.11.2018). - Назва з екрана.

12.Шостак А. В. Наукометричні показники i кар'єра вченого [Електронний ресурс] / Шостак А. В. // Академія наук вищої освіти України : [офіц. портал]. - Текст. дані. - Київ, [б. р.]. Режим доступу: http://anvou.org.ua/vidannya/nash-publikaciyi/shostak-av- naukometrichni-pokazniki-kareravchenogo/ (дата звернення: 21.11.2018). - Назва з екрана.

\section{References}

1. Bereziuk N. ORCID identyfikatsiia vchenoho [Elektronnyi resurs] / Nataliia Bereziuk // Pedahohichni nauky. Pereklad. - Tekst. dani. - [Ukraina], 2016. - Rezhym dostupu: http://edutranslate.wixsite.com/edutranslate/single-post/2016/06/17/ORCID-identyfikatsiia- vchenoho (data zvernennia: 16.11.2018). - Nazva z ekrana.

2. Borysova T. Rozbudova imidzhu naukovtsia suchasnymy zasobamy naukovoi komunikatsii [Elektronnyi resurs] : treninh dlia naukovtsiv / Tetiana Borysova ; Nauk. b-ka NaUKMA // Natsionalna medychna akademiia pisliadyplomnoi osvity imeni P. L. Shupyka : [ofits. portal]. -

Tekst. dani. - Kyiv, 2017. - Rezhym dostupu: http://nmapo.edu.ua/images/Novosti/24_10_18- 1.pdf (data zvernennia: 21.11.2018). - Nazva z ekrana.

3. Konovets O. F. Fakhova ta publichna reputatsiia vchenoho: komunikatyvnyi aspekt [Elektronnyi resurs] / Konovets O. F. // Nauk. zap. In-tu zhurnalistyky / Kyiv. nats. un-t im. Tarasa Shevchenka. - Tekst. dani. - Kyiv, 2007. - T. 28. - Rezhym dostupu: http://journlib.univ.kiev.ua/index.php?act=article\&article=1978 (data zvernennia: 21.11.2018). - Nazva z ekrana.

4. Lavrentii A. S. Osnovni pidkhody do identyfikatsii imidzhu, yoho strukturnykh skladovykh ta funktsionalnoho prostoru realizatsii / A. S. Lavrentii // Investytsii: praktyka ta dosvid. - 2017. - № 20. S. $123-128$.

5. Nazarovets C. Instrumenty dlia orhanizatsii vidkrytoho naukovoho spivrobitnytstva [Elektronnyi resurs] / Serhii Nazarovets // Profesiinyi rozvytok: vidkryti resursy, tsyfrova nauka ta mizhnarodni publikatsii : seminar, 5 hrud. 2014 r. / Kyiv. shk. ekonomiky. - Tekst. dani. - Kyiv,

2014. Rezhym dostupu:

https://www.researchgate.net/publication/271324903_Instrumenti_dla_organizacii_vidkritogo_nauk ovogo_spivrobitnictva (data zvernennia: 21.11.2018). - Nazva z ekrana.

6. Naukovtsi Ukrainy - novyi informatsiinyi blok portalu «Nauka Ukrainy: dostup do znan» [Elektronnyi resurs] // Natsionalna biblioteka Ukrainy imeni V. I. Vernadskoho : [ofits. portal]. - Tekst. dani. - Kyiv, 2017. - Rezhym dostupu: http://www.nbuv.gov.ua/node/3565 (data zvernennia: 21.11.2018). - Nazva z ekrana.

7. Paramonov S. Brend uchenoho: kak sdelat tak, chtobы nas tsytyrovaly [Эlektronnыi resurs] S. Paramonov // Clarivate Analytics. - Rezhym dostupa: http://wokinfo.com/media/pdf/ruresearcher_brand.pdf (data obrashchenyia: 21.11.2018). - Zahl. s эkrana.

8. Prysvoiennia DOI naukovym vydanniam [Elektronnyi resurs] // Internauka : vyd. dim.

- Tekst. dani. - Kyiv, [b. r.]. - Rezhym dostupu: https://www.internauka.com/ua/services/doi/ (data zvernennia: 21.11.2018). - Nazva z ekrana.

9. Semenenko L. P. Formuvannia brendu uchenoho / L. P. Semenenko, Yu. M. Hlavcheva, M. I. Hlavchev // Suchasni problemy diialnosti biblioteky v umovakh informatsiinoho suspilstva : materialy Shostoi mizhnar. nauk.-prakt. konf., 10-11 veres. 2015 r., Lviv / Nats. un-t «Lvivska politekhnika», Nauk.- 
tekhn. b-ka. - Lviv, 2015. - S. 22-27.

10. Systemy identyfikatsii naukovtsia [Elektronnyi resurs] // Naukova biblioteka Chernihivskoho natsionalnoho tekhnolohichnoho universytetu : [ofits. portal]. - Tekst. dani. - Chernihiv, [b. r.]. - Rezhym dostupu:

http://library2.stu.cn.ua/na_dopomogu_naukovcyu/sistemi_identifikacii_naukovcya/_(data zvernennia: 21.11.2018). - Nazva z ekrana.

11. Stvorennia unikalnykh profiliv doslidnyka v ORCID, Google Scholar ta in. [Elektronnyi resurs] // Naukova biblioteka Natsionalnoho universytetu «Kyievo- Mohylianska akademiia» : [ofits. portal]. - Tekst. dani. - Kyiv, [b. r.]. - Rezhym dostup: http://www.library.ukma.edu.ua/index.php?id=622 (data zvernennia: 21.11.2018). - Nazva z ekrana.

12. Shostak A. V. Naukometrychni pokaznyky i kariera vchenoho [Elektronnyi resurs] / Shostak A. V. // Akademiia nauk vyshchoi osvity Ukrainy : [ofits. portal]. - Tekst. dani. - Kyiv, [b. r.]. Rezhym dostupu: http://anvou.org.ua/vidannya/nash-publikaciyi/shostak-av- naukometrichni-pokaznikikarera-vchenogo/ (data zvernennia: 21.11.2018). - Nazva z ekrana.

\section{V. Horak,}

$\mathrm{PhD}$, Senior Researcher of scientific abstracts and analytical information in education department of the V. O. Sukhomlynskyi SSPL of Ukraine, Kiev, Ukraine

\section{INTERNATIONAL IDENTIFICATION SYSTEMS AS AN INDICATOR OF THE LEVEL OF A SCIENTIST}

The concept of a scientist's image has been defined in the article. Specific criteria features and functional capabilities of international systems of scientists' identification have been distinguished and analysed. It has been found out that the registration and creation of profiles in such communication systems is a desirable condition for a scientist's identification, an effective factor in increasing his professional competence. It has been specified that the mentioned systems provide an effective search for both parallel developers of scientific problems, potential co-authors and opponents and for prospective consumers of their products. At the same time, this is an expanded search for sources of funding for research activities. Emphasis has been placed on the popularization of their own research, the establishment of international relations in order to introduce Ukrainian scientists and the institutions they represented in the world scientific space. The author emphasizes the relevance of promoting the scientific works of domestic scientists to the international and world scientometric databases, which allows not only to share experience, but also to take into account the opinion of foreign researchers for the objectivity of obtaining intermediate and final results of thesis activity and planned research. The author provides a brief description of more popular identifiers (identifier systems), now they are the most important for the scientist's present activities, such as Scopus Author ID, Researcher ID, Open Researcher and Contributor ID (ORCID), Google Scholar Research Gate; focuses on the need for Crossref registration agencies to provide DOIs (Digital Object Identifiers) for each author's publication. It is also said in the article that the demonstration and popularization of the scientist's scientific activity takes place through the means of social networks such as Facebook, LinkedIn, Twitter, etc.

Keywords: identification, communication, social network, ORCID, ResearcherID, Google Scholar, DOI. 